\title{
How to read both: the logic of true contradictions in Chaucer's world ${ }^{1}$
}

Speculative thought consists only in this, in holding firm to contradiction and to itself in the contradiction. ${ }^{2}$

This essay begins with an assertion: that medieval culture, in manifest contrast with other periods, is characterized by the ubiquity and necessity of mutually exclusive truths.

Fundamental to medieval theology is the paradoxical relation of the human and the divine, an interdependence characterized by absolute otherness and total involvement. The central mystery of the God incarnate - the impossibly contradictory figure of abject man and transcendent God - stands at the core of reality, the point at which temporality and infinity meet. Human experience and suffering are nothing, in comparison with eternity - but human experience and suffering are everything, without which we have no access to eternity. One life is utterly trivial, considered in view of all history - but each soul is eternal, surviving and surpassing all history. This flickering of perspective is ubiquitous in medieval thought, as an epistemology shaped by theology, engaged in constant negotiation between this world and the next.

In this context Chaucer's Troilus reveals itself as the most delicate balancing act, juxtaposing profound contradictory truths, a temporal narrative of loss nested within the eternal spheres. Thousands of lines of human experience are gruellingly undergone, with agonizing conviction. At every moment the reality of feeling is brought to bear: the loneliness of subjectivity, the inaccessibility of justice, the impotent and absurd travails of the would-be moral agent, caught in the web of contingent circumstance and others' agency.

"Who shal now trowe on any othes mo?

Allas, I neuere wolde han wend, er this,

That ye, Criseyde, koude han chaunged so;

\footnotetext{
${ }^{1}$ I am extremely grateful to Steven Methven for lengthy conversations about philosophical logic, without which this essay would not exist; and to the anonymous readers for the journal, whose comments enabled me to improve it a great deal.

${ }^{2}$ G. W. F. Hegel, The Science of Logic, trans. George di Giovanni (Cambridge: Cambridge University Press, 2010), 383.
} 
$\mathrm{Ne}$, but I hadde agilt and don amys,

So cruel wende I nought youre herte, ywis,

To sle me thus! Allas, youre name of trouthe

Is now fordon, and that is al my routhe.

"Was ther non other broche yow liste lete

To feffe with youre newe loue," quod he,

"But thilke broch that I, with teris wete,

Yow yaf as for a remembraunce of me?

Non other cause, allas, ne hadde ye

But for despit, and ek for that ye mente

$\mathrm{Al}$ outrely to shewen youre entente.

"Thorugh which I se that clene out of youre mynde

Ye han me cast - and I ne kan nor may,

For al this world, withinne myn herte fynde

To unloven yow a quarter of a day!

In corsed tyme I born was, weilaway,

That yow, that doon me al this wo endure,

Yet love I best of any creature!"3

'Who will believe in any more promises?' asks the man whose own love has abandoned him; the answer is that everyone will, as they must: so grief singles out the injured from the pack. The lover speaks in a lost counterfactual past, a tense which betrays itself as he is betrayed - I would never have thought, I could not have believed - directly addressing a woman who does not hear and is not here: not because she is absent as the lady of fin' amor is absent, the light on the horizon, but quite the reverse; she has acted, seized agency, and turned away from one 'truth' in order to engender, pitifully, another ('To Diomede algate I wol be trewe': V.1071). Troilus insists it is her reputation for which he mourns, her 'name of trouthe', in a moment of direct parallel with Criseyde's own lamentations ('now is clene ago / My name of trouthe': V.1054-5), an echo which binds them even as they are severed, and economically invokes the whole intertextual world in which they are helplessly enmeshed. But the moment of empathy passes - as it must; empathy is hard exercise - and the rhetoric which follows is a bitter-keen

\footnotetext{
${ }^{3}$ Chaucer, Troilus and Criseyde, in The Riverside Chaucer, ed. Larry D. Benson (Oxford: Oxford University Press, 1988), V. 1681-1701.
} 
representation of the grief of betrayal. Troilus recurs to his conventional courtly themes with the mannered image of Criseyde's sovereignty, her enfiefing of one lover to follow another, and so devalues his own claim to individual passion. Interior experience is recast as public gesture, dissipating real feeling in symbols which take the place of reality - his show of tears, the brooch 'for remembrance', and her subsequent gift, made performative. Meaning here is stilted and conventionalized; Troilus' superlative grief is painfully unoriginal, but it is no less painful, indeed potentially more painful, for that. His interpretation of Criseyde's gift to Diomede as a message to himself demonstrates the lover's incapacity to see the beloved in relation to others; but it is also, abjectly, a plea - this much hurt must be intentional; carelessness would be a far greater pain. And so then Troilus moves, illogically, to probe that greater hurt: 'clene out of youre mynde / Ye han me cast'. The impossibility of recovery from this is tightly woven into the absurd coinage 'to unloven', and Troilus' understanding of his suffering is newly temporal, a burden to be carried a quarter of a day at a time. Criseyde's betrayal cannot, in fact, 'sle' him; he will die, but not for love. Finally, he bewails his 'corsed tyme': and comforting pattern though he finds it, he is wrong. Why does the one he loves best cause him all this hurt? Because only the one he loves best could cause him all this hurt. If he is fated, it lies in the necessities of human emotion, not the actions of the gods.

And then all this is swept away. Sustained psychological tenderness is replaced with impatience, even rage; with a kind of wearied contempt; and finally a striking out for eternity, an access of bliss, the ultimate promise.

And whan that he was slayn in this manere,

His lighte goost ful blisfully is went

Up to the holughnesse of the eighthe spere ...

And down from thennes faste he gan avyse

This litel spot of erthe that with the se

Embraced is, and fully gan despise

This wrecched world, and held al vanite

To respect of the pleyn felicite

That is in hevene above; and at the laste,

Ther he was slayn his lokyng down he caste,

And in hym self he lough right at the wo

Of hem that wepten for his deth so faste, 
And dampned al oure werk that foloweth so

The blynde lust, the which that may nat laste,

And sholden al oure herte on heven caste ...

Swich fyn hath, lo, this Troilus for love!

Swich fyn hath al his grete worthynesse!

Swich fyn hath his estat real above!

Swich fyn his lust, swich fyn hath his noblesse!

Swich fyn hath false worldes brotelnesse ...

Repeyreth hom fro worldly vanyte,

And of youre herte up casteth the visage

To thilke God that after his ymage

Yow made, and thynketh al nys but a faire,

This world that passeth soone as floures faire.

And loveth hym the which that right for love

Upon a crois, oure soules for to beye,

First starf, and roos, and sit in hevene above;

For he nyl falsen no wight, dar I seye,

That wol his herte al holly on hym leye. (V.1807-46)

The pace is inexorable; pitiless repetition ('Swich fyn'; later 'Lo here') is damning and liberating both; the argument, as with all arguments that compare earthly with divine, irresistible. Troilus crashes through the boundaries of his little, human, pagan world, and our perspective bursts with him, out into the eternal reality which lies beyond all things. But this is no retraction. The whole poem is balanced at the pivot point of Troilus' death: 8000 lines of human experience and suffering counter nine stanzas of divine truth. The point is that Chaucer weighs the two sides equally: holds them in tension, in contradiction; otherwise he would cast his little tragedy away. ${ }^{4}$

In Pearl, likewise, the Dreamer's grief is not dissipated or dismissed; it cannot merely be transmuted into divine knowledge. It is not even transcended by the truth of eternity;

\footnotetext{
${ }^{4}$ Cf. Peter H. Elbow, "How Chaucer Transcends Oppositions in the Knight's Tale," Chaucer Review 7.2 (1972), 97-112.
} 
instead the grief and the knowledge coexist. Language itself, likewise, is not changed but rather added to, augmented.

Perle, pleasaunte to prynces paye

To clanly clos in golde so clere ... ${ }^{5}$

I dewyne, fordolked of luf-daungere

Of pat pryuy perle wythouten spot. ... (11-12)

Pe grauayl pat on grounde con grynde

Wern precious perlez of oryente ... (81-2)

A mayden of menske, ful debonere;

Blysnande whyt wat3 hyr bleaunt.

I knew hyr wel, I hade sen hyr ere.

Pat gracios gay wythouten galle,

So smope, so smal, so seme slyzt,

Rysez vp in hir araye ryalle,

A precios pyece in perle3 py3t. ... (189-92)

Py3t wat3 poyned and vche a hemme

At honde, at syde3, at ouerture,

Wyth whyte perle and non oper gemme,

And bornyste quyte wat3 hyr uesture.

Bot a wonder perle wythouten wemme

Inmyddez hyr breste wat3 sette so sure ...

So wat3 hit clene and cler and pure,

Pat precios perle per hit wat3 py3t. ... (217-28)

He gef vus to be his homly hyne

Ande precious perlez vnto his pay. (1211-12)

As 'pearl' means, first a jewel, then the lost object of his love, then the promise of a strange land, then this stranger who is his daughter, then her glory in heaven and the symbol of her salvation, then the promise of salvation to all: it never loses any of those meanings; all are

\footnotetext{
${ }^{5}$ Pearl, in The Poems of the Pearl Manuscript, ed. Malcolm Andrew and Ronald Waldron (Exeter: University of Exeter Press, 1987), lines 1-2.
} 
true. Laws that govern the finite world - like the economic principle that a pearl found among thousands of pearls would be correspondingly reduced in value, or the linguistic and political principle that two queens are not queens at all - do not have purchase here. This is the realm of Kant's antinomies, the contradictions which necessarily arise in our attempts to understand transcendent reality. ${ }^{6}$ The Dreamer's grief remains unchanged at the end, and it remains true, as his loss is real; it is rather added to, held in balance, with the eternal truth that contradicts it.

These canonical examples serve here as archetypes of late medieval epistemology, which I think is fundamentally shaped by genuine contradiction: by mutually exclusive truths which cannot be reconciled and must simply be held fast, simultaneously. This is a specific and contentious claim, because it goes further than the well-recognized fact that dialectical opposition is central to medieval culture. ${ }^{7}$ The ubiquity of opposition per se, the idea that reality is shaped around contrasts and contraries, is by no means the same as the upholding of 'true contradictions'. Augustine wrote 'De pulchritudine universitatis, quae per ordinationem Dei etiam ex contrariorum fit oppositione luculentior' ('Of the beauty of the universe which, as God has arranged it, becomes even more brilliant by the contrast of opposites'), ${ }^{8}$ and contraries were broadly - even proverbially - understood to be essential to the understanding of reality: 'By his contrarie is every thyng declared. / For how myghte evere swetnesse han ben knowe / To him that nevere tasted bitternesse? ${ }^{\circ 9}$ This intuition was underpinned by the basic rules of dialectic, which provided for four categories of opposition. The first three of these are in the nature of (our perception of) reality: relative relations, such as great opposed to small; contraries, such as foolishness and wisdom; and qualities of possession or privation, such as blindness and sight. Contradiction, 'Cicero debates', 'Cicero does not debate' - the juxtaposition of thesis with antithesis, a proposition with its negation - was a sub-category,

\footnotetext{
${ }^{6}$ See, e.g., Graham Priest, Beyond the Limits of Thought (Oxford: Oxford University Press, 2002), chapter 6 (85-100).

${ }^{7}$ See, e.g., the brilliant study of Catherine Brown, Contrary Things: Exegesis, Dialectic, and the Poetics of Didacticism (Stanford, CA: Stanford University Press, 1998); she surveys traditional views of this opposition at $5-6$.

${ }^{8}$ Augustine, The City of God: Books VIII-XI, trans. David S. Wiesen (Cambridge, MA: Loeb, 1989), XI.xviii (494-5).

${ }^{9}$ Troilus and Criseyde, I.637-9.
} 
the final kind of opposition. ${ }^{10}$ Contradiction was of vital importance as the root of the quaestio, the discussion of thesis and antithesis which framed medieval disputation. It was the appearance of contradiction which drove logical enquiry, and hence the search for truth, as Abelard observed in the preface to his great collection of diversities in scripture, Sic et non:

His autem praelibatis placet, ut instituimus, diversa sanctorum patrum dicta colligere, quae nostrae occurrerint memoriae aliquam ex dissonantia quam habere videntur quaestionem contrahentia, quae teneros lectores ad maximum inquirendae veritatis exercitium provocent et acutiores ex inquisitione reddant. ${ }^{11}$

(It seems good, as I have resolved, to gather diverse sayings of holy fathers which have come to mind largely from the contradiction they seem to have in treating a question. They may challenge more inexperienced readers to the greatest proficiency in searching for the truth and, from their enquiry, render them more discriminating. $)^{12}$

But the point here is the apparent nature of contradiction. All authorities agreed that scripture could not contain untruth: 'Scripturas itaque canonicas veteris et novi testamenti dicit instrumenta, in quibus a veritate aliquid dissentire haereticum est profiteri.' ('[Augustine] calls the canonical writings of the old and new testaments "instruments", in which it is heretical to declare anything departs from the truth.' $)^{13}$ That being so, they could not contain genuine contradiction either, for it is in the nature of contradictory statements that while in some cases arguments may be marshalled on either side, as in the quaestio disputation, they cannot both simultaneously be true. Hugh of Saint-Victor observed that contradiction might appear on the surface of scripture - and might therefore contribute to the glorious variety of exegetical discourse - but contradiction itself could never be sustained as its true and full meaning:

\footnotetext{
${ }^{10}$ Martianus Capella, De nuptiis Philologiae et Mercurii, IV.384: 'opponuntur autem sibi ita, ut aut relativo opponitur, ut magnum parvo et dimidium duplo, aut contrarium, ut stultitia sapientiae, aut habitus orbationi, ut cernentia caecitati, aut aientia negationi, ut "Cicero disputat", "Cicero non disputat", quoted in Brown, Contrary Things, pp. 12-13. Cf. Alcuin, De Dialectica, cap. XI, 'De Contrariis vel oppositis', PL 101.963.

${ }^{11}$ Abelard, Sic et non, ed. Blanche B. Boyer and Richard McKeon (Chicago: University of Chicago Press, 1976-

7), Prologus, line 330 (my italics).

${ }^{12}$ Yes and No: the complete English translation of Peter Abelard's Sic et Non, trans. Priscilla Throop, $2^{\text {nd }}$ edn (Charlotte, VT: Medieval MS, 2008), 24-5 (my italics).

${ }^{13}$ Abelard, Sic et non, Prologus, line 292; trans. Throop, 23.
} 
Sententia diuina numquam absurda, numquam falsa esse potest, sed cum in sensu, ut dictum est, multa inueniantur contraria, sententia nullam admittit repugnantiam, semper congrua est, semper uera. ${ }^{14}$

(The divine deeper meaning can never be absurd, never false. Although in the sense, as has been said, many contrary things are found, the deeper meaning admits no conflict, is always harmonious, always true. $)^{15}$

John Wyclif rejected the idea of scriptural contradiction out of hand, with an impatience illustrative of a sense of danger; the word he uses (as with Hugh, above) is repugnancia, meaning not merely 'contradiction' but 'inconsistency', 'incompossibility' (and hence logical meaninglessness). ${ }^{16}$ The 'truth' of a quaestio, a usable contradiction, lies in and depends upon its either/or formulation: the question to be pursued and resolved is, is the proposition true, or false?

Quaestio vero est dubitabilis propositio. Propositio vero est ratio verum falsumve designans. ... Omnis enim quaestio contradictionibus constat. Nam si qua res ab altero affirmetur, negetur ab altero, totum hoc contradictio nuncupatur, ut si quis dicat: Coelum rotundum est, alter neget dicens: Coelum rotundum non est. Coelum rotundum esse, et non esse, contradictio prohibetur. ${ }^{17}$

(A quaestio is a proposition under debate. A proposition is a statement which can be designated as true or false. ... Something is asserted on one side, negated on the other, and the whole is called a contradiction, so one might say: the heavens are spherical, or negate it by saying: the heavens are not spherical. That the heavens are spherical and that they are not, is an impermissible contradiction.)

\footnotetext{
${ }^{14}$ Hugh of Saint-Victor, Didascalicon De Studio Legendi, ed. Charles Henry Buttimer (Washington, D.C.: The Catholic University Press, 1939), 6.11 (128).

${ }^{15}$ Trans. Brown, Contrary Things, 29. See her chapter 'Diversa sed non adversa: The Poetics of Exegesis', 1535 , on the 'both-and' plenitude of exegesis, which indulges in variety and contraries without allowing that there can ever be true contradiction.

${ }^{16}$ See Ian Christopher Levy, John Wyclif: Scriptural Logic, Real Presence, and the Parameters of Orthodoxy (Milwaukee: Marquette University Press, 2003), 102-9; quotation at 107, note 57. DMLBS, s.v. 'repugnantia', $3 c$.

${ }^{17}$ Boethius, In Topica Ciceronis Commentariorum, PL 64.1048D-1049B. On analysis of this passage see Peter Boschung, From a Topical Point of View: Dialectic in Anselm of Canterbury's De Grammatico (Leiden: Brill, 2006), 47-50.
} 
Dialectic excludes true contradictions by summoning up apparent ones, mutually exclusive propositions which can be supported in turn, or simultaneously by opposed disputants, but not simultaneously by any single thinker.

neque enim tota quaestio defenditur, sed una ejus quaelibet pars argumentatione firmatur: nemo enim defendit coelum rotundum esse et non esse. (1049A)

(It is not possible to defend the whole quaestio; rather one part is chosen to be supported in argument: no one can support the proposition that the heavens are and are not spherical.)

The purpose of dialectic was to move beyond contradiction to find truth; that very properly involved expressing and weighing the arguments on both sides, testing them against one another: but it did not, could not involve holding both the proposition and its negation to be true at once. Aristotelian logic was founded upon this principle, the law of non-contradiction, that a proposition and its negation cannot simultaneously be true. ${ }^{18}$ Medieval philosophy adhered precisely to Aristotle in this respect, maintaining its implications both for reality itself, and for our perception and understanding of reality:

scilicet quod impossibile sit idem esse et non esse. ... Ex hoc enim quod impossibile est esse et non esse, sequitur quod impossibile sit contraria simul inesse eidem. ... Et ex hoc quod contraria non possunt simul inesse, sequitur quod homo non possit habere contrarias opiniones, et per consequens quod non possit opinari contradictoria esse vera. ${ }^{19}$

\footnotetext{
${ }^{18}$ Aristotle formulated the principle in multiple ways in the Metaphysics, both supplying proofs for it and stating that it required no proof: "the most certain of all principles... "It is impossible for the same attribute at once to belong and not to belong to the same thing and in the same relation" ... it is impossible for anyone to suppose that the same thing is and is not'; 'the most certain of all beliefs is that opposite statements are not both true at the same time.' Aristotle, Metaphysics, Books I-IX, trans. Hugh Tredennick (Cambridge, MA: Loeb, 1933), IV.iii, 161-3; IV.vii, 199. See further S. Marc Cohen, 'Aristotle on the Principle of Non-Contradiction', Canadian Journal of Philosophy 16 (1986), 359-70; Patrick Grim, 'What is a Contradiction?', in The Law of Non-Contradiction, ed. Graham Priest, J. C. Beall, and Bradley Armour-Garb (Oxford: Oxford University Press, 2004), 49-71.

${ }^{19}$ Thomas Aquinas, In Aristotelis libros Metaphysicorum, ed. M.-R. Cathala and Raimondo Spiazzi (Taurini: Marietti, 1950), Book IV, lectio 6, no. 606. Cf. the Summa Theologica: 'primum principium indemonstrabile est quod non est simul affirmare et negare ... et super hoc principio omnia alia fundantur' ('the first indemonstrable principle is that "the same thing cannot be affirmed and denied at the same time" ... and on this principle all
} 
(We know that it is impossible for something to be and not be.... And from the fact that something cannot be and not be, it follows that it is impossible for contraries to inhere in the same thing at the same time. ... And from the fact that contraries cannot simultaneously inhere in a thing, it follows that a man cannot hold contrary beliefs, and consequently that it is not possible to imagine contradictions to be true.)

It was with this certainty in mind that Abelard had created his own compendium of quaestiones, gathering hundreds of contradictory scriptural passages in Sic et non. He called his work 'yes and no', indicating the sheer intellectual exercise and value of dialectic as a process, but he regarded all contradictions as no more than seeming, waiting to be resolved, and he phrased all of them in the either/or terms of the 'dubitabilis propositio': '1: Quod fides humanis rationibus non sit adstruenda et contra.' ('Faith must not be applied by human rationality ... Or it must be.' $)^{20}$ All questions are capable of being settled, even if they cannot be settled by a particular reader at a particular time; difficulty comes from our own inadequacy, not from any true contradiction. ${ }^{21}$

The ultimate end of the law of non-contradiction was set out logically in the twelfth century with the 'explosion principle', or ex contradictione quodlibet ('from contradiction, anything'): the proposition that if a contradiction is accepted, then anything at all may be proven - and so all logic is rendered null. ${ }^{22}$ Alexander Neckham gave a rapid explanation of the principle in De Naturis Rerum (probably written in the first decade of the thirteenth century):

Miror etiam quosdam damnare opinionem dicentium, ex impossibili per se quodcunque sequi enuntiabile. ... Nonne igitur si Sortes est homo, et Sortes non est

others are based': Aquinas, Summa Theologica, ed./trans. the Fathers of the English Dominican Province, 3 vols (New York: Benziger Brothers, 1947-8), vol. 1: $1^{\text {st }}$ part of $2^{\text {nd }}$ part, qu. 94, art. 2, online at <dhspriory.org/thomas/summa/index.html> [accessed July 2019].

${ }^{20}$ Trans. Throop, 31. See Brown, Contrary Things, 84-9.

21 'Quod si forte adeo manifesta sit controversia ut nulla possit absolvi ratione, conferendae sunt auctoritates, et quae potioris est testimonii et maioris confirmationis potissimum retinenda': Prologus, line 187. ('If perchance it is very clear that a controversy can be resolved by no reasoning, authorities must be consulted. What is of a more powerful testimony and greater firmness should, above all, be retained': trans. Throop, 18.) ${ }^{22}$ See Christopher J. Martin, ‘William's Machine', Journal of Philosophy 83 (1986), 564-72. The concept is also widely known to modern philosophy as ex falso quodlibet, which itself demonstrates the status of contradictions in classical logic. 
homo, Sortes est homo? Sed si Sortes est homo, Sortes est homo vel lapis; ergo, si Sortes est homo, et Sortes non est homo, Sortes est homo vel lapis; sed si Sortes est homo, et Sortes non est homo, Sortes non est homo; ergo si Sortes est homo, et Sortes non est homo, Sortes est lapis. Consimili deductione, probabitur quod si Sortes est homo et Sortes non est homo, Sortes est capra, et ita de singulis rebus, puta rosa, lilio, et cæteris rebus. ${ }^{23}$

(I wonder that certain men oppose the thesis that from a per se impossibility anything whatsoever follows ... For doesn't it follow that if Socrates is a man and not a man, then Socrates is a man, but if Socrates is a man, then Socrates is a man or a stone. Therefore, if Socrates is a man and not a man, than Socrates is a man or a stone. But if Socrates is a man and not a man, then Socrates is not a man. Therefore, if Socrates is a man and Socrates is not a man, then Socrates is a stone. By a similar deduction, it can be proven that if Socrates is a man and not a man, then Socrates is a goat, and so for anything - say a rose, a lily, or anything else at all. $)^{24}$

In terms of logical notation, the principle can be set out as follows:

$$
\begin{array}{ll}
\mathrm{P} \wedge \neg \mathrm{P} & \text { Assume that }(P \text { and not- } P) \text { are true } \\
\mathrm{P} \wedge \neg \mathrm{P} \rightarrow \mathrm{P} & \text { If }(P \text { and not- } P) \text { are true then } P \text { is true } \\
\mathrm{P} \vee \mathrm{Q} & \text { If } P \text { is true, then for any arbitrary } Q,(P \text { or } Q) \text { is true } \\
\mathrm{P} \wedge \neg \mathrm{P} \rightarrow \neg \mathrm{P} & \text { But given that }(P \text { and not- } P) \text { are true then not- } P \text { is true } \\
\mathrm{P} \vee \mathrm{Q} \rightarrow \mathrm{Q} & \text { So given that not }-P \text { is true and }(P \text { or } Q) \text { is true then } Q \text { is true } \\
\mathrm{P} \wedge \neg \mathrm{P} \rightarrow \mathrm{Q} & \text { So if we accept }(P \text { and not }-P) \text { then } Q, \text { for any arbitrary } Q .
\end{array}
$$

There are reasons to doubt the validity of this principle,${ }^{25}$ and the twentieth and twenty-first centuries have seen the development of various schools of 'paraconsistent logic', drawing on arguments for the possibility of contradiction, to which I will return. Nonetheless, most

\footnotetext{
${ }^{23}$ Alexander Neckham, De Naturis Rerum Libri Duo, ed. Thomas Wright (London: Longman, 1863), 288-9.

${ }^{24}$ Part trans. in Martin, 'William's Machine', 571.

${ }^{25}$ See Graham Priest, 'What's So Bad About Contradictions?', in The Law of Non-Contradiction, ed. Priest et al., 24-9.
} 
modern philosophy cannot and does not dispense with the law of non-contradiction; some philosophers even regard it as indisputable. ${ }^{26}$

However, as I began this essay by suggesting, thinkers in the Middle Ages had some profound reasons to question the law of non-contradiction. ${ }^{27}$ The nature of God had always threatened to transcend any such law, from the early Church fathers onward.

The divine unity is beyond being ... the indivisible Trinity holds within a shared undifferentiated unity. . . . the assertion of all things, the denial of all things, that which is beyond every assertion and denial ... ${ }^{28}$

It is important to note what is and is not thought to be at stake here, however. The quest to understand transcendent divinity was never intended to stand in opposition to logic; rather it lies at the root of apophatic mysticism. Aristotelian logic was the foremost tool of philosophical enquiry, a system defined by its universal validity and regarded as a manifestation of natural reason; to challenge it in any sphere risked tearing the divine wholly away from human understanding, and throwing into question all rational enquiry. ${ }^{29}$ Nonetheless, the nature of the divine posed dangerous questions. Omnipotence itself created logical paradoxes, most readily (and unavoidably) summed up in the scriptural statement that 'negare seipsum non potest' ('God cannot deny himself': 2 Tim 2:13). Pseudo-Dionysius had invented in his own work a foolish interlocutor's attempts thereby to deny God's omnipotence, and stated that the objection was nugatory; Paul Vincent Spade has observed that medieval authors, in sharp contrast with modern philosophers, seem to have regarded the well-known insolubilia 'more as nuisances than as crucial theoretical test-cases' ${ }^{30}$

\footnotetext{
${ }^{26}$ See David Lewis, 'Letters to Beall and Priest', in The Law of Non-Contradiction, ed. Priest et al., 76-7.

${ }^{27}$ See, e.g., Alan Philip Darley, 'Does Aquinas' Notion of Analogy Violate the Law of Non-Contradiction?', The Heythrop Journal 54 (2013), 228-37. For an overview juxtaposing 'Augustinian' with 'Aristotelian' views of contradiction see Sarah Kay, Courtly Contradictions: The Emergence of the Literary Object in the Twelfth Century (Stanford: University of California Press, 2001), 11-25.

${ }^{28}$ Pseudo-Dionysius, The Divine Names, 2.4, quoted in Darley, 'Does Aquinas?', 230. Cf. Pseudo-Dionysius, The Mystical Theology, ch. 1, in Dionysius the Areopagite: On the Divine Names and the Mystical Theology, ed./trans. C. E. Rolt (London: SPCK, 1920).

${ }^{29}$ Philotheus Boehner, "The Medieval Crisis of Logic and the Author of the "Centiloquium" Attributed to Ockham', Franciscan Studies 4.2 (1944), 151-70 (152); Hester Goodenough Gelber, 'Logic and the Trinity: A Clash of Values in Scholastic Thought, 1300-1335', unpubl. PhD dissertation (University of Wisconsin, 1974), 4-5.

${ }^{30}$ Paul Vincent Spade, 'Recent Research on Medieval Logic', Synthese 40.1 (1979), 3-18 (8).
} 
Nevertheless, in his commentary on Pseudo-Dionysius' text Aquinas himself made a renewedly serious attempt to tackle the paradoxes of omnipotence, reaffirming a resolution of the scriptural crux:

et dicit quod, cum Deus sit ipsa veritas, Deum negare seipsum, nihil aliud est quam Deum decidere a veritate. Cum autem verum idem sit quod ens, sequitur quod excidere a veritate, idem sit quod excidere ab esse. Quod ergo dicit Deum non posse negare seipsum, idem est ac si diceretur: Deum non posse deficere ab essendo. ... sicut et si dicatur quod Deus non potest non posse, non ostendit quod sit impotens, sed quod sit maxime potens; et similiter, si dicatur quod non cognoscit se nescire ita quod habet scientiae privationem, hoc est ipsum habere perfectam scientiam. Per hoc ergo quod Deus non potest negare seipsum, nihil detrahitur eius potentiae ab impossibili, sed idem est ac si diceretur, quod Deus non potest non esse verus et ens et potens. (And he says that, since God is truth itself, for God to deny himself is nothing other than for God to fall away from the truth. But since the true is the same as being, it follows that to fall completely away from truth is to fall completely away from being. Therefore, what he says - that God cannot deny himself - is the same as if he were to say: God is not able to fall short of being. ... Just as if it should be said that God is not able to be unable, this does not show that he is powerless, but that he is supremely powerful; and similarly, if it should be said that he does not know that he does not know, and therefore that he has privation of knowledge, this is the very having of perfect knowledge. Through this, therefore, that God cannot deny himself, nothing is detracted from his power by the impossible, but it is the same as if it were said that God cannot not be true and being and powerful.) $)^{31}$

As a resolution of the contradiction, this is an answer that rests on the transcendent nature of God alone. Abelard's framing of his Sic et Non is a fascinating exposure of this problem for human thought: following that preface insisting on the mere 'appearance' of contradiction, he already shows unease by recommending an ultimate appeal to authority when truth cannot be found, and no argument can carry the matter. ${ }^{32}$ In the main text there is little comfort to be had from the long series of questions, each furnished with unimpeachable scripture in extracts

\footnotetext{
31 Thomas Aquinas, In Dionysii De diuinis nominibus, ed. C. Pera, (Marietti: Taurini, 1950), 8.1; trans. Father Joseph Vnuk, quoted in Darley, 'Does Aquinas?', 230-1. Cf. The Divine Names, 8.6.

${ }^{32}$ See above, note 21 .
} 
which flatly contradict one another. While some are soluble on the authority of current doctrine, others seem to me to be unresolved, unresolvable contradictions that cut to the heart of the Catholic faith:

Quod Deus personam hominis non susceperit sed naturam et contra. (God received not the identity of a human being, but his nature ... or not.)

Quod filius Dei mutatus sit suscipiendo carnem et non. (The Son of God changed in taking flesh ... or not.)

Quod Deus et homo in Christo partes esse videantur et non. (God and the human being are seen to be parts in Christ ... or not.)

Quod in Christo is qui est filius Dei non sit ille qui est filius hominis sive is qui est aeternus non sit is qui est temporalis et contra. (In Christ, the one who is Son of God is not the one who is the Son of Man, or he who is eternal is not the one who is temporal ... or he is. $)^{33}$

The mystery of the incarnation appears inherently contradictory, for man and God are subjects with negative relation: man is not God, and God is not man. But Christ is God, and Christ is man: and therefore logic insists that Christ is God and is not God, is man and is not man. In classical logic this would be a reductio ad absurdum, a circular disproof of the premise that 'man is not God'; but in the Christian universe we cannot dispense with that premise. ${ }^{34}$ The only resolution to this contradiction is the miraculous mystery at the centre of the faith: Christ him- (and Him-)self, both embodied on earth and enthroned in heaven. This has powerful resonance with Hegel's core notion of the contradiction in all things, and the ultimate transcendent resolution of that contradiction. ${ }^{35}$ Hegel famously states that " AAll

\footnotetext{
${ }^{33}$ Abelard, Sic et non, qus. 64, 65, 66, 75; trans. Throop, 154-6; 176.

${ }^{34}$ A Hegelian philosopher might resolve the contradiction by positing that the conclusion is valid because the way in which Christ is God is different from the way in which Christ is man: that is, that the identity of Christ with God and the identity of Christ with man is different in each case. I owe this observation to Steven Methven (private communication). The fourteenth-century author of the controversial Centiloquium (once attributed to William of Ockham), despite arguing that Aristotelian logic could not be applied to the Trinity, similarly upheld the principle of non-contradiction as it pertained to the divine essence in Son and Father: Boehner, 'Medieval Crisis of Logic', 156-7.

35 Andrew Cole has argued for the dependence of Hegel's thought on specifically medieval models of dialectic: see The Birth of Theory (Chicago: University of Chicago Press, 2014), 34-57. For Graham Priest, Hegel's arguments support the existence of true contradictions and hence anticipate dialetheism (on which see below): In
} 
things are in themselves contradictory"', and lauds contradiction as the greatest of all principles of existence: 'identity is only the determination of simple immediacy, of inert being, whereas contradiction is the root of all movement and life; it is only in so far as something has a contradiction within it that it moves, is possessed of instinct and activity. ${ }^{36}$ Robert Pippin has sought to explain the origins of this difficult claim. ${ }^{37}$ It seems that any proposition (subject-predicate) which places a universal in the predicate position will automatically generate a contradiction. That is, if we state that 'Socrates is man', then because 'Socrates' is a particular example, where 'man' is a universal, the proposition is both true and untrue: Socrates is man, but he is not the whole identity of 'man', because other people are (hu)man too. There is an immediate objection available: 'Has he not obviously confused here, as [Bertrand] Russell complained, the "is" of predication with the "is" of identity? ${ }^{38}$ In general it does not seem problematic to say that a subject can have the properties of a predicate, without being identical with that predicate. But as Pippin observes, 'far from having overlooked this issue, Hegel considers it as the heart of what he is interested in claiming. His whole point is that the "is" in question for an essential determination must always be the "is" of identity ... we are interested not in what properties [the subject] $s$ happens to have but in just what $s$ is so that it can have properties'. And as such, if we confine ourselves to saying that the subject has such-and-such properties, and not that it is identified with some predicate, then we will never be able to say what the subject $i s$. So contradiction is inherent to being: everything the subject is, it is not. If that is abandoned, then we have abandoned the attempt to say what anything is; we have abandoned the quest for knowledge. ${ }^{39}$

Contradiction, 1-4. Michael Wolff regards Hegel's apparent support for contradiction as a 'scandal ... out of the bounds of any ordinary logic', but adds that 'it is difficult to find a logic on the basis of which Hegel's theory of contradiction is vulnerable': 'On Hegel's Doctrine of Contradiction', trans. Erin Flynn and Kenneth R.

Westphal, The Owl of Minerva 31 (1999), 1-22 (19). For a recent attempt to reconcile Hegel's philosophy with the law of non-contradiction see Karin de Boer, 'Hegel's Account of Contradiction in the Science of Logic Reconsidered', Journal of the History of Philosophy 48.3 (2010), 345-73.

${ }^{36}$ Hegel, Science of Logic, trans. Giovanni, 381-2.

${ }^{37}$ Robert B. Pippin, 'Hegel's Metaphysics and the Problem of Contradiction', Journal of the History of Philosophy 16.3 (1978), 301-12 (309-10).

38 Pippin, 'Hegel's Metaphysics', 310.

${ }^{39}$ Cf. James Kreines, Reason in the World: Hegel's Metaphysics and its Philosophical Appeal (Oxford: Oxford University Press, 2015), 193-6; 248-9. 
But for Hegel, there is a final step:

This contradictoriness of course resolves itself into nothing: it goes back into its negative unity. A thing, a subject, a concept, is then precisely this negative unity; it is something inherently self-contradictory, but it is no less the resolved contradiction; it is the ground which contains the determinations it bears. (Science of Logic, 384)

I am at the limits of my understanding here. ${ }^{40}$ But it seems to me that this might serve most effectively (albeit against Hegel's expressed intention of describing all reality) as a description of Christ: the God-man, the ultimate contradiction, only (and entirely) resolved in the essence of his own existence. Christ is God and is what God is not, is man and is what man cannot be: but he is himself the miraculous ground in which this contradiction is resolved. We might go further, by analogy with the original distinction between particular subject and universal predicate: because Christ both is particular (only Christ is Christ) and shares full identity with the universal. That is, Christ is God, wholly; Christ is man, wholly, in a way that Socrates was not, because Christ stands for all humanity, and in the most profound way possible, because he stands so before God. So Christ's (unique) particularity, which is (uniquely) absolutely identified with the universal, is the miraculous resolution of Hegel's contradiction.

That said, I think we find ourselves compelled to return to Hegel's subject-predicate contradiction with the further mystery of the Trinity. ${ }^{41}$ It would seem that while Christ is man - he is essentially to be identified with the universal of humanity, in a way that is not true of any other human - it remains logically possible to say that he both is and is not God, because the Father and the Holy Spirit are also God, but not Christ. This is only one way of expressing the logical challenges posed by the Trinity; from the first emergence of the scholastic project to apply logic to theology, the mystery at the heart of the faith had provided

\footnotetext{
${ }^{40}$ And relieved to discover that I am not alone: Pippin, 'Hegel's Metaphysics', 301-2; Theodor W. Adorno, 'Skoteinos, or How to Read Hegel', in Hegel: Three Studies, trans. Shierry Weber Nicholsen (Cambridge, MA: MIT Press, 1993), 89.

${ }^{41}$ See e.g. Pseudo-Dionysius, The Divine Names, 2.5: 'The Father alone is the Source of the Super-Essential Godhead, and the Father is not a Son, nor is the Son a Father; for the Divine Persons all preserve, Each without alloy, His own particular Attributes of praise. Such, then, are the instances of Undifference and of Differentiation in the Ineffable Unity and Subsistence of God.'
} 
stern resistance, becoming mired in unacceptable syllogisms. ${ }^{42}$ The fourteenth century saw several attempts to resolve the difficulty, tackling both the nature of God, and the nature of logic. William of Ockham (1285-1347) put forward an argument which sought to dismiss the contradictory syllogisms as fallacies, by insisting on limiting the formal characteristics of their subjects. For a syllogism to be valid, Ockham specified, the premises must be two singular propositions, and the subject of each proposition must be singular and unique: not, that is, a universal, or a commonly-held characteristic. ${ }^{43}$ So just as it is a false syllogism to say that 'Socrates is man; Plato is man; therefore Socrates is Plato' (rather, Socrates is a human being just as Plato is a human being), it is false to say that 'the Father is the divine essence; the Son is the divine essence; therefore the Father is the Son': rather, the two persons are distinct, and share in the divine essence. ${ }^{44}$ This was not a simple matter, however, because the two examples are profoundly different in kind: the divine essence is God, and God is Father, is Son, and is Holy Spirit, even as they are not the same; they are distinct and yet one. The Trinity conceives of identity and distinction in a wholly unique way. The Fourth Lateran Council had in its opening statement decreed it to be beyond human understanding, 'incomprehensibilis et ineffabilis pater et filius et spiritus sanctus tres quidem personae sed una essentia substantia seu natura simplex omnino' ('incomprehensible and ineffable, Father and Son and Holy Spirit, indeed three persons but one essential substance, a wholly single nature'), ${ }^{45}$ and Ockham's equivocations about the subjects of syllogisms could not easily throw further light on this transcendent reality. But what Ockham was trying to rescue - and in this he was joined by numerous colleagues - was not human understanding of the Trinity,

\footnotetext{
${ }^{42}$ One ubiquitous example: 'The Son is the divine essence; the Father is the divine essence; therefore the Son is the Father.' Boehner, 'Medieval Crisis of Logic', 154-5; 157-8; 168.

${ }^{43}$ William of Ockham, Summa Logicae, ed. Philotheus Boehner, Gedeon Gál, and Stephen Brown (St Bonaventure, NY: Franciscan Institute, 1974), 3.1, chs. 4-5, 16; see Boehner, 'Medieval Crisis of Logic', 15863.

${ }^{44}$ Ockham, Summa Logicae, 3.1, ch. 16, 24-33: 'Unde sicut non sequitur "homo est Sortes; homo est Plato; ergo Plato est Sortes", ita si haec humanitas una numero esset Sortes et Plato, et simul cum hoc Sortes et Plato essent plures homines, non sequeretur "haec humanitas est Sortes; haec humanitas est Plato; igitur Plato est Sortes". Et hoc quia haec propositio "haec humanitas est Plato" verificaretur quia Plato est Plato, et haec propositio "haec humanitas est Sortes" verificaretur quia Sortes est Sortes, et propter hoc haec humanitas est tam Sortes quam Plato. Ex isto patet quare iste syllogismus non est expositorius "haec essentia est Pater; haec essentia est Filius; igitur Filius est Pater", quia scilicet haec essentia est plures personae distinctae.'

${ }^{45}$ Concilium Lateranense IU, in Conciliorum Oecumenicorum Decreta, ed. J. Alberigo, J. A. Dossetti, P. P. Joannou, C. Leonardi, P. Prodi, and H. Jedin, LLT-A (Turnhout: Brepols, 2010), 230-71, Constitutio 1 (230).
} 
but Aristotelian logic itself. ${ }^{46}$ If it could not be used without contradiction in the divine realm, then its universality - its formal quality - was lost; could such a system then sustainably be used in any sphere at all? Fourteenth-century thinkers judged that in the face of this crisis some adjustments could be made, because Aristotle could not have known the nature of God, knowledge given only by revelation. They therefore redefined the rules of syllogisms and fallacies precisely in order to prove that the peculiar character of the divine does not render logic null. ${ }^{47}$ The aim was to demonstrate that there is no flaw in logic itself, that it retains universality: and that, as such, it can be applied to the divine without breaking its own rules, including the principle of non-contradiction. ${ }^{48}$

However, in relying on the generation of fallacies (that is, the dismissal as invalid of syllogisms which could not be made to apply to God), such arguments progressively limited logic's range of application, exposing its apparent inadequacy in the divine realm, and once again threatening its universality. ${ }^{49}$ In response, some theologians developed arguments for a wholly different species of logic applicable to the divine, which would leave Aristotelian logic untouched, but confined to the created world. The English Dominican Robert Holcot (c. 1290-1349) most famously rejected Ockham's fallacies and instead proposed a separate logica fidei, a logic of faith distinct from that of the natural order, logica naturali. ${ }^{50}$ But he too maintained the law of non-contradiction in both systems (indeed, the virtue of his logica fide $i$ was that it dispensed with contradiction as no more than an appearance, consequent on the limitations of human understanding). ${ }^{51}$ The unknown author of the Centiloquium theologicum (formerly attributed to Ockham) ${ }^{52}$ went so far as to conclude that the nature of

\footnotetext{
${ }^{46}$ For an account of several variations on this strategy, see Gelber, 'Logic and the Trinity', 235-60.

47 'Attempts to amend the Church's definition of God so that God would conform with Aristotelian logic, increasingly gave way in the fourteenth century to attempts to amend and supplement Aristotelian logic to conform with the Church's definition of God': Gelber, 'Logic and the Trinity', 11.

48 Boehner, 'Medieval Crisis of Logic', 163-7.

${ }^{49}$ Gelber, 'Logic and the Trinity', 260-1.

${ }^{50}$ Robert Holcot, Sententiarum 1.4, quoted by Hester Goodenough Gelber, Exploring the Boundaries of Reason:

Three Questions on the Nature of God by Robert Holcot, OP (Toronto: Pontifical Institute of Mediaeval Studies, 1983), 26-7 (n. 72). On the relation of Holcot to Ockham see William J. Courtenay, Ockham and Ockhamism: Studies in the Dissemination and Impact of His Thought (Leiden: Brill, 2008), 117-20.

${ }^{51}$ Gelber, Exploring the Boundaries, 27-8; 'Logic and the Trinity', 266-70; Boehner, 'Medieval Crisis of Logic', 169-70.

${ }^{52}$ Philotheus Boehner, 'The Centiloquium Attributed to Ockham', Franciscan Studies 1.1 (1941), 58-72.
} 
the Trinity invalidates the formal universality of pre-Christian logic: ${ }^{53}$ but he argued that revelation allowed for an adjustment to and improvement upon that logic, not its destruction, and he upheld the law of non-contradiction. ${ }^{54}$ Following Duns Scotus, he suggested a rule of pronominal reference to the divine essence, and to the persons of the Trinity, capable of expressing their relations in formal terms, without contradiction. ${ }^{55} \mathrm{He}$ stated that although the persons of the Trinity are the same in number - that is, they are a singular being - they are not 'convertibly', interchangeably, the same: for if they were, then the divine essence would be the same as, and nothing other than, the Son, which is not true. Therefore even though contradictory predicates are proposed of those who are (indeed, better to say 'the one who is') the same, this is not a contradiction, 'quia non idem convertibiliter demonstratur, quod ad veram requiritur contradictionem' ('for it is clearly not convertibly the same, which is what makes a true contradiction'). But 'hoc est in illa materia singulare' ('this is uniquely so in this matter'): only in God can one subject both be and not be the same as itself. ${ }^{56}$ The difficulties - not to mention the essential circularity - of all these arguments were keenly felt by medieval theologians. ${ }^{57}$ The problem was to some degree intractable, as Ernest Moody has observed: 'entailed by the fact that the eternal, necessary, and predictable natural world of Aristotle had been replaced by the created, contingent, and only conditionally predictable natural order compatible with the Christian Faith. ${ }^{58}$

In sum, I want to suggest that medieval thought was continually pushed towards the possibility of true contradictions, despite the constant reaffirmation of their impossibility

\footnotetext{
${ }^{53}$ Boehner, 'The Centiloquium', 64.

${ }^{54}$ Boehner, 'Medieval Crisis of Logic', 156-7.

55 Gelber, 'Logic and the Trinity', 283-91.

${ }^{56}$ Philotheus Boehner, ed., 'The “Centiloquium” Attributed to Ockham: Part VI', Franciscan Studies 2 (1942), 251-301 (271-2).

57 'Even in the time of St Thomas Aquinas, the lines of the battle were drawn; for those who argued, in the thirteenth century, against the distinction between a natural and a supernatural order, were already eliminating causes and substances from the created world and reducing physics to theology': Ernest A. Moody, 'Ockham, Buridan, and Nicholas Of Autrecourt: The Parisian Statutes of 1339 and 1340', Franciscan Studies 7 (1947), 113-146 (141).

${ }^{58}$ Moody, 'Ockham, Buridan, and Nicholas Of Autrecourt', 142. Cf. Hester Goodenough Gelber, 'Laughter and Deception: Holcot and Chaucer Remain Cheerful', in Uncertain Knowledge: Scepticism, Relativism, and Doubt in the Middle Ages, ed. Dallas G. Denery II, Kantik Ghosh, and Nicolette Zeeman (Turnhout: Brepols, 2014), 285-304 (285-6).
} 
imposed by classical logic; and that this tension gives rise to extreme creativity in thought, and to a moral and ethical epistemology which has a great deal to teach us.

Take a proposition: We are not worthy of God's love. This is demonstrably true: We are created, and fallen; sinful, flawed. We are not of the same stuff as God; we can never be his equal; we can never return his love, because we lack his capacity; and in our ontological capacity as free beings we have proved ourselves unworthy, by sinning. But simultaneously, the statement must be untrue: for God loves us; this is proven by the incarnation and the Passion. Can it be that this is not a contradiction, because God can love that which is not worthy of his love? No, because God's love renders the beloved worthy, as Julian of Norwich explained:

He shewed a littil thing the quantitye of an hesil nutt... It is all that is made. I mervellid how it might lesten, for methowte it might suddenly have fallen to nowte for littil. And I was answered in my understondyng, It lesteth and ever shall, for God loveth it; and so all thing hath the being be the love of God. ${ }^{59}$

God's love is creation itself; it is the principle by which all reality is made and sustained, essential to our nature. And yet that same love does not work over time to change us, does not transform us from unworthy to worthy; if it did, it would destroy our free will, remove our souls' agency. So: I contend that the proposition 'Mankind is not worthy of God's love' is both true and untrue; it is a 'true contradiction'.

There is an obvious objection to be made: is this explained (indeed, might all apparently true contradictions be explained) by inconsistencies in language? In this example, are we merely equivocating over the meaning of the word 'worthy'? I think not, though I am not disputing that its meaning might shift. The poem Pearl demonstrates the accretive polysemy of language in this period, a phenomenon which emerges from words' necessary signification of multiple levels of reality - the literal, the earthly, the imaginary, the divine, the eternal. We understand that the Pearl-Maiden is a 'queen' (for her claim relies upon faith; it must be accepted) even as we understand that this word queen is not functioning in the same way, or by the same rules, as the earthly word queen.

Aquinas explains the multiplicity of language in the Summa Theologica:

\footnotetext{
${ }^{59}$ Julian of Norwich, A Revelation of Love, ed. Marion Glasscoe (Exeter: University of Exeter Press, 1993$), 7$.
} 
omnes rerum perfectiones, quae sunt in rebus creatis divisim et multipliciter, in Deo praeexistunt unite [...] puta cum hoc nomen sapiens de homine dicitur, significamus aliquam perfectionem distinctam ab essentia hominis, et a potentia et ab esse ipsius, et ab omnibus huiusmodi. Sed cum hoc nomen de Deo dicimus, non intendimus significare aliquid distinctum ab essentia vel potentia vel esse ipsius. Et sic, cum hoc nomen sapiens de homine dicitur, quodammodo circumscribit et comprehendit rem significatam, non autem cum dicitur de Deo, sed relinquit rem significatam ut incomprehensam, et excedentem nominis significationem. Unde patet quod non secundum eandem rationem hoc nomen sapiens de Deo et de homine dicitur.

(All perfections existing in creatures divided and multiplied, pre-exist in God unitedly [...] for instance, by the term 'wise' applied to man, we signify some perfection distinct from a man's essence, and distinct from his power and existence, and from all similar things; whereas when we apply to it God, we do not mean to signify anything distinct from His essence, or power, or existence. Thus also this term 'wise' applied to man in some degree circumscribes and comprehends the thing signified; whereas this is not the case when it is applied to God; but it leaves the thing signified as incomprehended, and as exceeding the signification of the name. Hence it is evident that this term 'wise' is not applied in the same way to God and to man. $)^{60}$

The insight works by analogy and extrapolation, and we gain some partial understanding of the nature of heaven; language is being used inconsistently, but not incoherently.

The current living philosopher who champions the concept of true contradictions, Graham Priest, argues that the inconsistency of language is itself proof that inconsistency need not entail incoherence (a term which means the destruction of all logic): 'incoherence should at least be taken to entail unusability... [The Explosion Principle states] that if a contradiction were true, everything would be true. Hence language would be unusable ... [but] the usability of an inconsistent language follows naturally from the fact that one is used. ${ }^{91}$ If language can be inconsistent without being incoherent, he says, so can reality. On this, as we have seen, the Middle Ages were some way ahead. Medieval theories of grammar and logic dwelt on the inconsistencies of language usage which give rise to apparent contradictions - the change in signification or supposition which renders a syllogism

\footnotetext{
${ }^{60}$ Aquinas, Summa Theologica, $1^{\text {st }}$ part of $1^{\text {st }}$ part, qu. 13, art. 5.

${ }^{61}$ Priest, In Contradiction, 5-6.
} 
invalid. ${ }^{62}$ But beneath this understanding of language's uneven use was the assurance that it nonetheless had a natural relation to reality; that, indeed, reality had been composed of the divine language, and that the created world was theoretically susceptible of being sufficiently comprehended by language. The difficulty that rendered such understanding theoretical, as with the inaccessibility and incomprehensibility of God, was post-lapsarian human limitation.

cetera dici possunt utcumque; ille solus est ineffabilis, qui dixit, et facta sunt omnia. Dixit, et facti sumus: sed nos eum dicere non possumus. Verbum eius quo dicti sumus, Filius eius est; ut a nobis utcumque infirmis diceretur, factus est infirmus.

(All other things may be expressed in some way; he alone is ineffable, who spoke, and all things were made. He spoke, and we were made; but we are unable to speak of him. His Word, by whom we were spoken, is his Son. He was made weak, so that he might be spoken by us, despite our weakness. $)^{63}$

This is the culture which begins with the Word, and is saved by the Word made flesh. God spoke, and all things were made; Adam in Eden was able to name all creatures; but the Fall deracinated human language, separating it from the divine reality. ${ }^{64}$ Only with the verbum caro factum, the miraculous re-illumination of the material, mortal universe by the eternal reality beyond it, can human language be recuperated, such that we may speak of God - and that is to say, speak truth, speak of reality as such, rather than of this mortal fragility. Language exists first and truly in the mind of God, and that language creates and instantiates all reality - in response to which our language only regains and accretes meaning as it returns towards God. And yet God cannot be directly spoken of, for all human language is limited by human understanding. As the pearl that is the jewel we prize becomes the pearl that is the prize worth more than the universe, so we can see that inconsistencies of language do not amount to an incoherence in reality. If language is inconsistent, it is because there is more

\footnotetext{
${ }^{62}$ See, e.g., Gillian R. Evans, 'A Work of “Terminist Theology”? Peter the Chanter's De Tropis Loquendi and Some Fallacie', Vivarium 20.1 (1982), 40-58.

${ }^{63}$ Augustine, Enarrationes in Psalmos, ed. D. Eligius Dekkers and Ioannes Fraipont (Turnhout: Brepols, 1956), 99. 6; trans. Marcia L. Colish, The Mirror of Language: A Study in the Medieval Theory of Knowledge, $2^{\text {nd }}$ edn (Lincoln NE: University of Nebraska Press, 1983), 26.

${ }^{64}$ See, e.g., E. Jennifer Ashworth, 'Aquinas, Scotus and Others on Naming, Knowing, and the Origin of Language', in Logic and Language in the Middle Ages: A Volume in Honour of Sten Ebbesen, ed. Jakob Leth Fink, Heine Hansen and Ana María Mora-Márquez (Leiden: Brill, 2013), 257-72.
} 
than one kind of reality: and language, coming from God, and providing the bridge between God and man, is equipped to express the resultant contradictory truths.

Priest has coined the term dialetheia for true contradictions, which can be defined very simply:

$$
\mathrm{T} \alpha \wedge \neg \alpha \quad \text { It is true that } \alpha \text { and that not }-\alpha \text {. }
$$

The first challenge is to feel our way to what it would mean to believe that both a proposition and its negation were true. How can we live with true contradictions, without losing our way? I am suggesting that despite the best efforts of medieval philosophers to resolve them, or to declare them impossible, true contradiction is one of the defining characteristics of medieval literature and thought. But believing in a true contradiction is hard. I think the reality of this struggle is what lies at the heart of a scene notorious for its 'baffling complexity': ${ }^{65}$ Piers' tearing of the pardon in Passus 7 of the B text. Here is dramatized an encounter with true contradiction, and the result is figural violence, the tearing apart of a logical chain of reasoning. Truth had reaffirmed the command to Piers to work the land as a 'pilgrym atte plow', 66 promising him 'a pardoun a pena et a culpa / For hym and for hise heires for everemoore after' (7.3-4). But the pardon, when it comes, is apparently no such thing:

'Piers', quod a preest thoo, 'thi pardon moste I rede;

For I shal construe ech clause and kenne it thee on Englissh.'

And Piers at his preiere the pardon unfoldeth -

And I bihynde hem bothe biheld al the bull

In two lynes it lay, and noght a lettre moore,

And was writen right thus in witnesse of truthe:

Et qui bona egerunt ibunt in vitam eternam.

Qui vero mala, in ignem eternum.

'Peter!' quod the preest thoo, 'I kan no pardon fynde

But "Do wel and have wel, and God shal have thi soule,"

And "Do yvel and have yvel, and hope thow noon oother

That after thi deeth day the devel shal have thi soule!"”

\footnotetext{
${ }^{65}$ Denise N. Baker, 'Pre-Empting Piers's Tearing of the Pardon: Langland's Revisions of the C Visio', The Yearbook of Langland Studies 31 (2017), 43-72 (44).

${ }^{66}$ William Langland, The Vision of Piers Plowman: a critical edition of the B-text based on Trinity College Cambridge MS B.15.17, ed. A. V. C. Schmidt, $2^{\text {nd }}$ edn (London: Dent, 1995), 6.102.
} 
And Piers for pure tene pulled it atweyne

And seide, 'Si ambulavero in medio umbre mortis

Non timebo mala, quoniam tu mecum es.

'I shal cessen of my sowyng,' quod Piers, 'and swynke noght so harde,

Ne aboute my bely joye so bisy be na moore;

Of preieres and of penaunce my plough shal ben herafter,

And wepen whan I sholde slepe, though whete breed me faille.' (7.105-21)

Numerous scholars have written persuasively on this crux, ${ }^{67}$ and I want only to add that I think we can read that moment of tearing in two as the strain of the 'AND' term in the dialetheia. It is true that we are pardoned for our sins, and it is true that we must strive moment by moment against sin; it is true that we are saved by grace, by an unearned gift, and it is true that our works lead to salvation or damnation. It is true, more specifically to the dilemmas of this part of the vision, that scripture says to work and to cultivate the earth, and that scripture enjoins us to consider the lily. To dowel will save us, but no guidance will tell us what that means: to work or to pray, to plough or go on pilgrimage. As in the rest of this whole, elusive, dialetheic poem, these contradictions cannot be resolved: they can only be lived. As the dispute continues Will is ejected from the dream and left to wander, burdened with the confusion of its true contradictions. ${ }^{68}$

The preest and Perkyn apposeden either oother

And I thorugh hir wordes awook, and waited aboute,

And seigh the sonne in the south sitte that tyme.

Metelees and moneilees on Malverne hulles,

Musynge on this metels a myle wey ich yede.

${ }^{67}$ See, e.g., Alastair J. Minnis, 'Piers' protean pardon: Langland on the letter and spirit of indulgence', in Translations of Authority in Medieval English Literature: Valuing the Vernacular, ed. Minnis (Cambridge: Cambridge University Press, 2009), 68-89; Baker, 'Pre-Empting Piers's Tearing'; Emily Steiner, Documentary Culture and the Making of Medieval English Literature (Cambridge: Cambridge University Press, 2003), 12142; Rosemary Woolf, 'The Tearing of the Pardon', in Piers Plowman: Critical Approaches, ed. S. S. Hussey (London: Methuen, 1969), 50-75. David A. Lawton argues for fruitful paradox in the act in 'Piers Plowman: on tearing - and not tearing - the pardon', Philological Quarterly 60 (1981), 414-22.

${ }^{68}$ Anne Middleton has observed that numerous episodes in the text end with such a threatening critical impasse: 'Narration and the Invention of Experience: Episodic Form in Piers Plowman', in The Wisdom of Poetry: Essays in Honor of Morton Bloomfield, ed. Larry Benson and Siegfried Wenzel (Kalamazoo: Medieval Institute Publications, 1982), 91-122. 
Many tyme this metels hath maked me to studie

Of that I seigh slepynge - if it so be myghte;

And for Piers the Plowman ful pencif in herte,

And which a pardon Piers hadde, al the peple to conforte,

And how the preest inpugned it with two propre wordes. (7.139-48)

Will ends his reflections with an unresolved contradiction that slips past with the ease of familiarity - a prayer binding grace and works together: 'That God gyve us grace here, er we go hennes / Swiche werkes to werche' (7.198-9). He settles on Dowel as the safest principle, but he must 'leve leelly (Lordes forbode ellis!) / That pardon and penaunce and preieres doon save' (7.178-9). These contradictions cannot be resolved, and authority remains uncertain. ${ }^{69}$

The sense of crisis that this engenders has practical force. These are not abstract questions of theological interpretation, but moral dialetheias which leave human agency mired in doubt, weighed down by the sole certainty of moral responsibility. How is one to act on these contradictory, true propositions? As Nicolette Zeeman has shown, Langland's Will makes some effort to argue, with frustrated confusion, that his only response can be inaction; in return multiple answers are given in refutation of his nihilism, but none provides resolution. ${ }^{70}$ Arguing from a philosopher's point of view for the existence of moral dialetheias, Priest comments on the 'cold comfort' that 'when these arise, a practical problem is posed with which dialetheism gives no help'. Contrarily, he describes from first principles the 'divine command theory of morality' which would be capable of excluding moral dialetheias, by combining 'transcendent standards of morality' with a benevolent god who 'would not issue inconsistent commands'. ${ }^{71}$ As we have seen, this was precisely the reasoning - that omnipotence is confined by the law of non-contradiction - that sustained the logic of medieval theology. ${ }^{72}$ The implications of this promise in the moral sphere must

\footnotetext{
${ }^{69}$ Nicolette Zeeman writes that Langland 'ostentatiously refuses all but the briefest moments of reconciliation and the most minimal forms of clarification': 'Pastoral Care by Debate: The Challenge of Lay Multiplicity', Journal of Medieval and Early Modern Studies 48 (2018), $435-59$ (450).

70 Zeeman, 'Pastoral Care by Debate', 447-50.

${ }^{71}$ Priest, In Contradiction, 246-7. He does not accept that such a god need be bound by the law of noncontradiction - though it might be argued that this represents a circularity in his argument for moral dialetheias. 72 Philosophers noted the difficulty of this concept by using the hypothetical example of the uneducated layperson (often the vetula, the 'little old lady'), who would instinctively be unable to reconcile omnipotence with non-contradiction: see Christophe Grellard, 'How Is it Possible to Believe Falsely? John Buridan, the Vetula, and the Psychology of Error', in Uncertain Knowledge, ed. Denery, Ghosh and Zeeman, $91-113$ (102).
} 
surely be that because God does not issue contradictory commands, there can be no genuinely incompatible moral obligations. All that remains as an explanation for our crisis, then, is our own ignorance and lack of understanding: our incoherence, as we encounter what seem to be contradictions, and like Will risk falling into despair, acedia. I want to examine a canonical literary example of a character's nihilistic incoherence, as an object lesson in why the notion of contradiction was so threatening. To be clear, I believe in the existence of moral dialetheias, and in their half-acknowledged presence in Piers Plowman: medieval culture more broadly is poised between exploring them and denying them, as I will elaborate further below. First, however, and in some ways in absolute opposition with true contradiction, the matter of incoherence - which is to say, the problem of moral unusability.

What are the implications of believing in the truth of a proposition, $\alpha$ ? Jean Buridan (1300-1358) argued for a separation between assent and acceptance, as explained by Christophe Grellard:

The intellect, either spontaneously or through deliberation, produces an initial cognitive assent, 'This is true'. This assent entails the first act of the will which is the first act of the appetite. This act is completely determined by the judgement of the intellect and is an act of pleasure or pain. This entails a second act of will, peculiar to man, which is an act of acceptance (or effective appetite). This act, under certain conditions, is free, but once produced it inevitably entails action. ${ }^{73}$

In similar terms, Graham Priest establishes the matrix within which contradictory propositions may be accepted, rejected, or held in uncertainty:

We may say of someone who believes that $\alpha$, who behaves in whatever ways it is appropriate to behave in virtue of this, accepts $\alpha$. If someone does not accept or believe $\alpha$, we may distinguish two further cases. They may not just fail to believe $\alpha$, but positively refuse to believe it; that is, they may reject it. On the other hand they may neither believe it nor refuse to believe it, but remain agnostic. ... First, acceptance and rejection are not exhaustive, but they are exclusive. They are not exhaustive since being agnostic is a third possibility. In particular, therefore, rejecting something is not the same as not believing it. It is much stronger. ${ }^{74}$

\footnotetext{
${ }^{73}$ Grellard, 'How Is it Possible', 95-6.

${ }^{74}$ Priest, In Contradiction, 122.
} 
These fine distinctions enable us to explore a literary example, not of true contradiction, but of an author's toying self-consciously with a character's incoherence, his lived contradictions: this figure is Chaucer's Pardoner. The Pardoner is a notoriously disturbing character, whose physical strangeness and moral vacuity have troubled critical analysis. ${ }^{75}$ Suppose our proposition, $\alpha$ is the statement 'there is eternal judgement after death'. The most unnerving aspect of the Pardoner - perhaps physically embodied in his contradictory gender signals, which I think have nothing to do with gender, and everything to do with contradiction - is the fundamental contradiction, of his behaviour. The Pardoner is not an atheist; he is not even agnostic. He does not fail to believe $\alpha$; he does not believe not- $\alpha$ : that is, he assents to the proposition 'there is eternal judgement after death'. He might even be said to accept the proposition, in that he preaches and sermonizes to that effect, he asserts its truth; he attempts to persuade others of its truth, and he succeeds. But in his soul - in his will - he rejects it. He behaves as though he thinks 'there is no eternal judgement after death', which is effectively to say, 'there are no consequences to sin'. But he does not believe that. He pursues avarice and harm, even while knowing that he is damning himself to hell. He performs rejection without believing negation. He lives out an absolute contradiction. He is, in short, Satan.

This is clarified by considering an alternative approach to the proposition: that of the atheist. The atheist does not believe the rejection of $\alpha$, 'there is no eternal judgement after death', and respond by pursuing sinful gain. Instead she negates, regards as untrue, the proposition that 'there is eternal judgement after death'. The agnostic, similarly, is not agnostic between 'there is eternal judgement' and its active rejection, 'there is no eternal judgement': rather she is agnostic about whether the statement 'There is eternal judgement after death' is true, or not. This is an important difference, which bears upon action and judgement.

In logical terms, the two situations can be expressed as follows:

\section{The Pardoner's incoherence}

$\mathrm{T} \alpha \wedge \mathrm{T} \neg \alpha \quad$ It is true that (There is eternal judgement after death)

AND it is true that (there is no eternal judgement after death)

\footnotetext{
${ }^{75}$ For a summary of psychoanalytic approaches and a strong case for a historicist one, see Lee Patterson, 'Chaucer's Pardoner on the Couch: Psyche and Clio in Medieval Literary Studies', Speculum 76 (2001), 638-80.
} 


\section{Reality}

$\mathrm{T} \alpha \vee \neg \mathrm{T} \alpha \quad$ It is true that (There is eternal judgement after death)

\section{OR it is not true that (There is eternal judgement after death)}

This, then, is the answer to the ancient accusation that atheism logically implies immorality. ${ }^{76}$ The atheist simply does not assent to the proposition that 'there is eternal judgement after death', in the same way she does not accept that 'there is waterpolo after death'. The proposition has no bearing on her moral identity; it is (she believes) not true, and hence (in her epistemology) it is non-existent: and hence it is immaterial to her existence. There is no particular behaviour appropriate to the (already negated) statement 'it is not true that there is eternal judgement after death'; it requires, and implies, no action at all. ${ }^{77}$

The inconsistencies of Chaucer's Pardoner's logic expose the dissonance, the incoherence, that makes him such a disturbing presence. When, having crowed to the pilgrims at length about the fraudulence and fakery of his trade, he then invites the Host to kiss his relics, he is not merely offering an insult about the man's being 'moost envoluped in synne'. ${ }^{78} \mathrm{He}$ is implying that all men live his own false contradiction: that while everyone believes in God's judgement, everyone lives as though they do not - and, crucially, that they are all aware of their own hypocrisy. This is how he threatens to take all the pilgrims down to hell with him: with his open falsity, he steals from them the defence of 'invincible ignorance' - the principle that someone acting in good faith is protected from the consequences of (unwitting) $\sin .{ }^{79}$ What he offers with his greasy assurances is terrible, nihilistic complicity,

\footnotetext{
${ }^{76}$ Famously atheism is excluded from the liberal religious freedoms of Thomas More's Utopia: 'they believe that after this life punishments are ordained for vices and rewards for virtues. Anyone who thinks otherwise they do not even include in the category of human beings ... since he would set no store whatever by all their laws and morality if it were not for fear.' Thomas More, Utopia, trans. Clarence H. Miller, with Jerry Harp, $2^{\text {nd }}$ edn (New Haven: Yale University Press, 2014), 119.

${ }^{77}$ For a distinction between 'denial' and 'assertion of a negation', and the argument that the former should not be interpreted as the latter, see Greg Restall, 'Multiple Conclusions', in Logic, Methodology and Philosophy of Science: Proceedings of the Twelfth International Congress, ed. Petr Hajek, Luis Valdes-Villanueva and Dag Westerstahl (London: Kings' College Publications, 2005), 189-205.

78 The Pardoner's Tale, in The Riverside Chaucer, line 942.

79 This was a matter of active debate in fourteenth-century England, with Robert Holcot the strongest advocate of 'invincible ignorance': Hester Goodenough Gelber, It Could Have Been Otherwise: Contingency and Necessity in Dominican Theology at Oxford, 1300-1350 (Leiden: Brill, 2004), 298.
} 
speaking as one sinner to another. He relies on the frightening, true assertion that no route to salvation is certain; in response to that anxiety, he urges that they can purchase tokens of spurious comfort, pay to admire his worthless relics: which is a way of giving up, and showing that they have given up, all hope of grace. Even the suggestion is fatal, for as an insight of meaninglessness it interposes itself into all circumstances of doubt, both retrospectively and in future: should the charitable giver seek to know the moral value and deserving of the recipient? Has she always been certain of it? If not, then her doubt on the matter vitiates the gift as potentially immoral; if contrarily she seeks resolution in finding out the absolute deserving of the recipient, she risks excluding charity at all. This is a crisis provoked here by the Pardoner's incoherence, his open declaration of his own falsehood: it robs his interlocutors of good faith, in every sense of that term.

What his worthless relics signify - what, indeed, the figure of the Pardoner himself stands to claim - is that the ritual of devotion is devotion; that there is nothing true, nothing beneath. The Pardoner's epistemology is void at its heart. ${ }^{80}$ The Host is filled with righteous horror in response, a horror which reveals not disinterested distaste for the Pardoner's moral vacuity, but genuine fear that he will be infected by the Pardoner's damnation:

"Com forth, sire Hoost, and offre first anon,

And thou shalt kisse the relikes everychon,

Ye, for a grote! Unbokele anon thy purs."

"Nay, nay!" quod he, "thanne have I Cristes curs!

Lat be," quod he, "it shal nat be, so theech!” (lines 943-7)

The Host's disgust is instinctive. The Pardoner's lived contradictions have nothing to do with genuine moral dialetheias; he is instead the logical extension of human ignorance and despair, the spiritual acedia that results from losing the will to live with uncertainty. The result is a repulsive and compulsive incoherence, a spectacle of ultimate self-harm.

This is not a trivial danger, because of the profound strictures we have traced in Christian logic. Medieval epistemology demanded that people retain their faith in the law of non-contradiction, even in the face of towering moral uncertainty. The most powerful promise of medieval Christian thought is its assertion that right action will always be clear,

\footnotetext{
${ }^{80}$ Cf. Carolyn Dinshaw on the Pardoner's 'fundamental refusal to know': Chaucer's Sexual Poetics (Madison, WI: University of Wisconsin Press, 1989), 159.
} 
whether or not an individual is capable of performing it; and that in any case, on the grandest scale, justice will always be done. It is in this sense that the Middle Ages have often been said to be an age without tragedy - in Auerbach's phrase, 'there are no conflicts which deserve to be called tragic' - there is loss, and suffering, but never without clarity of duty, and never without ultimate reparation. ${ }^{81}$ But of course, as I have already suggested (and as so many medieval authors evidently knew), this is nonsense. Terry Eagleton speaks of the roots of tragedy in contradiction, 'the curse of our condition [which] is also the source of our creativity':

[T]his dimension of human existence, which is at once traumatizing and liberating, is of course much older than the modern ... For the middle ages, the chief title for this dangerous ambivalence was God, whose ruthlessly unconditional love will burn us up (God himself is the fire of hell) unless we have hijacked for ourselves some of its power, a power which knows no bounds in its mercy and tenderness and which is therefore terrible to look upon. For Aquinas, God is at once quite other to us, and closer to us than we are to ourselves ...82

We cannot sustain the idea that God is separate from us - and how would we, when God too is human? But that God is human means that we share in divinity - we are his, and all of one another's, 'blody bretheren' ${ }^{83}$ - and as such, we are no mere creatures or instruments, but full and whole moral agents. Eagleton observes the absolute indissolubility of our existence not only from this supreme Other, but from all others, and the inescapable moral hazard which results:

How can we not be guilty simply by existing, when, given that we are bound up with each other as intimately as breathing, the most innocent of our actions may breed dire consequences in the lives of others? ${ }^{84}$

From this we can see that the most profound dialetheias arise in the moral sphere; merely by virtue of our shared existence, we are unavoidably enmeshed in mutually exclusive moral

\footnotetext{
${ }^{81}$ Erich Auerbach, 'Roland against Ganelon', in Mimesis, trans. Willard R. Trask (Princeton: Princeton University Press, 1953), 96-122 (110).

${ }^{82}$ Terry Eagleton, 'Commentary [on Michel Maffesoli et al., 'The Return of the Tragic in Postmodern Societies']', New Literary History 35 (2004), 151-9 (152-3).

${ }^{83}$ Piers Plowman, 11.201; see Emily Steiner, Reading Piers Plowman (Cambridge: Cambridge University Press, 2013), 78-80.

${ }^{84}$ Eagleton, 'Commentary', 153.
} 
obligations. It is not clear, and cannot be clarified, how we should weigh our moral duty to others, and to ourselves. What is our obligation to a parent, a child, a spouse, a neighbour, a stranger, all of humanity? What obligation do we have to our own thriving? Can one person be justifiably sacrificed for another? With a will, or unwillingly? These are the essential questions of moral philosophy, and they generate difficulties which I believe can be regarded as true contradictions.

In early pastoral teaching the church attempted to resolve these contradictions by placing the soul's obligation to God above all others, explicitly derogating all human relationships as not just inferior to that with God, but positively dangerous to the fulfilment of one's obligations to God. ${ }^{85}$ By these lights there are no moral dialetheias, for there can be no conflicting moral obligations. So it was that Christina of Markyate, asked by the voice of God whether she would sacrifice her best friend's life, was delighted to say that she would kill him joyfully if God required it of her:

Quem pro me tantopere diligis. pro cuius salute me sollicitare non desinis. velles ut pro me mortis subiret angustias? Clamore illa sed interiori affectu ingente non voce constanter respondit. Illud quidem Domine gratanter sed et si vestra pateret voluntas propriis manibus gratancius complerem.

('He whom you love so much for my sake, for whose salvation you continue to implore, would you like him to suffer death for my sake?' With a cry, but inwardly, with a great surge of feeling, but in silence, she replied at once: 'That indeed, o Lord, I gladly desire, and if thy will was plain, I would even more gladly carry it out with my own hands.' $)^{86}$

Derogation of the world enabled the resolution of contradiction, by establishing only one, supreme obligation: but it came at the cost of the eradication of human (and humane) relation. Strict orthodoxy on this cannot have been sustained by practising preachers, whose aim must be to understand and to ameliorate the lives of their parishioners. ${ }^{87}$ More profoundly, as Piers Plowman shows, that blood brotherhood of Christ and humanity which is central to the faith explicitly contradicts the claim that human beings do not owe one another obligations: and

\footnotetext{
${ }^{85}$ See Laura Ashe, The Oxford English Literary History vol. 1: 1000-1350. Conquest and Transformation (Oxford: Oxford University Press, 2017), 95-101, 182-3, 333-9.

${ }^{86}$ The Life of Christina of Markyate, ed./trans. C. H. Talbot (Oxford: Clarendon Press, 1959), 180-1.

${ }^{87}$ See Laura Ashe, 'The Originality of the Orrmulum', Early Middle English 1.1 (2019), 33-54.
} 
moreover, obligations of multiple kinds, both freely and involuntarily undertaken, baffling in their complexity and interrelation.

All epistemological reflection, in the Middle Ages, necessarily had the nature of a training in negative capability. Beside that abstract mental exercise, human imagination is shaped by human experience, as literature by life: and life is teeming with moral conflicts. As narrative fiction emerged in the twelfth century in the form of the romance, it sought to explore social relations, the ethics of human daily life in idealized forms. Authors trained in Aristotelian logic naturally deployed the tools at their disposal, and dialectic was brought to bear upon the dilemmas of social life. ${ }^{88}$ But dialectic, of course, was the science of exploring contradiction in order to resolve it. Chrétien de Troyes's romances are full of apparent contradictions, performative moral dilemmas set out for debate as quaestiones, which the knight is able to resolve as he grows in understanding of chivalry. Repeatedly a protagonist is faced with competing obligations, and he experiences the agony of having to choose between mutually exclusive goods (and harms):

D’angousse a .i. souspir jetié, Que pour le royaume de Tharse

$\mathrm{Ne}$ vaurroit que chele fust arse

Quë il avoit asseüree.

Sa vie avroit courte duree

Ou il istroit tous vis du sens

S'il n'i pooit venir a tens.

Et d'autre part en tel destreche

Le retient le grant gentilleche

Monseigneur Gavain son ami

C'a paines ne li fent par mi

\footnotetext{
${ }^{88}$ Tony Hunt, 'Aristotle, Dialectic, and Courtly Literature', Viator 10 (1979), 95-129; see also (on Andreas Capellanus and the Libro de buen amor) Brown, Contrary Things, chapters 4 and 5, 91-144. Sarah Kay, Courtly Contradictions, has argued that courtly literature emerged from the pursuit of unstable contradictions; see also Kay, 'Contradiction and Abjection in the Tristan of Thomas and the Poetry of Marcabru', in Études de langue et de littérature médiévales offertes à Peter T. Ricketts à l'occasion de son 70ème anniversaire, ed. Ann Buckley and Dominique Billy (Turnhout: Brepols, 2010), 27-36; Virginie Greene, Logical Fictions in Medieval Literature and Philosophy (Cambridge: Cambridge University Press, 2014).
} 
Li cuers, quant demourer n'i puet. ${ }^{89}$

(He [Yvain] sighed deeply in his anguish, because, on the one hand, he would not for all the wealth of Tarsus want to see her whom he had sworn to help be burned to death; his life would reach its end or he would go completely mad if he could not arrive in time to save her. Yet, on the other hand, memory of the great nobility of his friend, my lord Gawain, caused him such distress that his heart nearly burst in two since he could stay no longer.)

His heart is almost split down the middle, 'par mi', by this crisis, rendering the apparent contradiction of his mutually exclusive obligations in physiological terms. But the suspense is short-lived; Yvain's superlative chivalry enables him to fulfil both, and to resolve the contradiction in grateful triumph. Moral hazard here is a game, a playful process with a happy ending.

Elsewhere, however, the romance rapidly pursued some real moral dialetheias. Supreme among these are Thomas of Britain's representation of Tristan's non-negotiable obligations to his lover, to himself, and to his wife.

'L'une e l'altre pur mei se dolt,

E jo m'en duil pur duble Ysolt.

Supris en sunt andui de mei,

A l'une, a l'altre ment ma fei;

A la reïne l'ai mentie,

A ceste n'en pois tenir mie. 90

('Both the one and the other suffers on my account, and now I suffer for Yseut and her double. I have conned both of them, broken my promises to the one and the other; I have lied to the queen, and I cannot hold loyally to this one.')

All four actors in this drama - Tristan and Yseut, Yseut's husband King Mark, Tristan's wife Yseut of the White Hands - are simultaneously bound together and held asunder by suffering. There is no course of action which could fulfil all obligations, nor any which can be said to

\footnotetext{
${ }^{89}$ Chrétien de Troyes, Le Chevalier au lion, ou, Le Roman d'Yvain, ed. David F. Hult (Paris: Le Livre de Poche, 1994), lines 4070-81.

${ }^{90}$ Thomas of Britain, Tristan, ed. Stewart Gregory, in Early French Tristan Poems: Vol. 2, ed. Norris J. Lacy (Cambridge: D. S. Brewer, 1998), lines 524-9.
} 
be morally right without the exclusion of alternative moral rightness; nor even any course of action which might promise to minimize suffering. Pain is incommensurable - subjectivity is tragedy, for it excludes knowledge of justice: individual experience cannot be compared, as individuals cannot be weighed one against another - and that is at the heart of all moral contradiction; and it is also at the heart of all reading. Fiction is the mode which imagines others as whole individuals with inner lives, capable of incurring complex obligations to one another - indeed, incapable of avoiding becoming enmeshed in others' lives. Fiction, then, is the justified falsehood, itself inherently contradictory, which exercises empathy even while acknowledging its impossibility, speaking of something real and essential which can only be approached via the inventions of imagination. It is only possible to say that a full attention to the contradiction, to the incommensurable and unknowable but nonetheless absolutely real suffering of others, is the basis of a moral existence.

Very few philosophers accept dialetheism, the existence of true contradictions. No one disputes, however, that life as it is lived can seem overwhelmed by them. I have argued that medieval literature is supremely attentive to their felt ubiquity, and I think that this gives us, now, access to some useful modes of understanding. It is true, for example, that each individual can only speak of their individual experience - and that no one else may speak of it - but it is equally true that society cannot exist if we practise that truth; if we abandon the quest for empathy then we are lost. Gayatri Chakravorty Spivak has written of the urgent necessity, in a global age, of 'learning to live with contradictory instructions'. ${ }^{91}$ Medieval thinkers were much better than us at seeing these contradictions as the nature of reality. ${ }^{92}$ The result is a life's work: not an abdication of moral judgement, but a profound insight to the incommensurability of all moral phenomena, precisely balanced with the absolute necessity for universal moral clarity.

\footnotetext{
${ }^{91}$ Spivak, An Aesthetic Education in the Era of Globalization (Cambridge: Harvard University Press, 2012), 1.

${ }^{92}$ Sarah Kay suggests that modern critics have shown a curious blindness to the contradictions in twelfthcentury literature: Courtly Contradictions, 8-11.
} 